\title{
The Relationship between Corporate Social Responsibility and Employer Attractiveness in Egypt: The Moderating Effect of the Individual's Income
}

\author{
Nayera Ahmed Fouad Ibrahim \\ German University in Cairo \\ E-Mail: nayera.ahmed@gmail.com
}

\begin{abstract}
Corporate social responsibility activities can generate many forms of competitive advantage. Employer attractiveness, among others, is one them. Simultaneously, the global talent shortage and the national labor market dynamics render talent attraction a big challenge for organizations in Egypt. The relationship between corporate social responsibility and employer attractiveness was neither tested in Egypt, nor moderated by the individual's income. The main motivation behind this study is to close these gaps. For this purpose, the conceptual framework proposes that there is a positive relationship between corporate social responsibility and employer attractiveness, and that this relationship is moderated by the individual's income. The study was conducted at a private university in Cairo. Masters of business administration students were surveyed using non-probability convenience sampling. Data were analyzed using one-way and two-way Analysis of Variance. Findings indicate that there is a strong positive relationship between socially responsible organizations and their attractiveness as employers. Supporting Carroll's 1979 framework of the relative importance of corporate social responsibility dimensions, the economic responsibility has the highest effect on employer attractiveness, followed by the legal responsibility, and then the discretionary one. Results also show that the individual's income does not moderate the relationship. These findings act as a valuable guide for human resources practitioners on how to develop an effective employer branding strategy.
\end{abstract}

Keywords: Competitive Advantage, Corporate Social Responsibility, Egypt, Employer Attractiveness, Employer Branding, Human Resources, Individual's Income 


\section{INTRODUCTION}

In the last few decades, the importance of Corporate Social Responsibility (CSR) has grown massively (Sousa Filho, Wanderley, Gómez, \& Farache, 2010). The widespread attention to CSR has raised scholars' interest to understand the types of competitive advantage an organization may acquire when acting in a socially responsible manner (Albinger \& Freeman, 2000). Empirical research has associated CSR with various forms of competitive advantage (Sousa Filho et al., 2010). Among which are good image and reputation, cost savings, CSR-related risk reduction or management, revenue increase from higher sales and market share, and the positive impact on human resources' motivation, retention, and attraction (Weber, 2008).

Human resources are considered a major driving force of many organizations that are equipped with financial resources and the latest technologies (Shahzad, Gul, Khan, \& Zafar, 2011). Yet, the acquisition of human resources remains a major challenge and one of the principal business problems (Ramasamy, Yeung, \& Yuan, 2008). There exists a substantial level of competition among organizations to attract the best talent in the market due to the global talent shortage problem (Bergen, 2008).

The situation is more challenging in Egypt due to the intricacies of the labor market dynamics (Hassan \& Sassanpour, 2008). First, there is a mismatch between the quality of supply and that of demand (Birdsall \& O'Connell, 1999; Galal, 2002). Despite the high percentage of high school and college graduates, the theoretical nature of the educational content fails to deliver and produce the required labor market skills (U.S. Department of the Army, 1998). Moreover, the expatriation of skilled personnel, seeking higher wages and salaries and better quality of living, adds to the problem as well (Ahmed, Guillaume, \& Furceri, 2012; Birdsall \& O’Connell, 1999; U.S. Department of the Army, 1998). Organizations are fiercely competing to attract the scarce talents and constantly complaining that the insufficient supply hampers the implementation of business plans (U.S. Department of the Army, 1998).

In an attempt to attract the most qualified candidates, organizations need to be attractive employers through managing their image and the perceptions about themselves in the minds of job seekers (Shahzad et al., 2011). Empirically, CSR has been proved to be an effective reputation management strategy that is formulated to attract prospective employees (Kim \& Park, 2011). Thus, the strategic deployment of CSR in the labor marketplace can assist organizations to win the war over talent and pave the way towards organizational success (Ramasamy et al., 2008).

The purpose of this study is to understand whether a high-performing CSR organization yields an attractive employer in Egypt or not. It also aims at identifying 
the relative importance of the economic, legal, and discretionary dimensions of CSR to the Egyptian job seekers. In addition, it seeks to determine whether the individual's income moderates his/her attraction to high-performing CSR organizations or not.

\section{LITERATURE REVIEW}

\section{Corporate Social Responsibility}

Varying definitions and frameworks of CSR can be traced back starting the 1950s. CSR has evolved over time until it reached ISO 26000 - Social Responsibility in 2010 (Carroll, 1999; ISO - International Organization for Standardization, 2017). However, this study adopts Carroll's 1979 definition for two reasons. First and foremost, the research questions and hypotheses anchor on it. The study is conducted in a developing country whereby the fundamental responsibilities of organizations are still questionable. Egypt has been suffering from an unstable economic situation as a result of the 2011 revolution and the persistent political turmoil. In addition, illegal business transactions and unethical employment practices are widely spread in the country. This makes Carroll's 1979 framework, which outlines the most fundamental corporate responsibilities, an ideal foundation for this research. Although Carroll revisited this model in 1983 and 1991, he didn't change it. He suggested that the most secondary corporate responsibilities are considered voluntary and philanthropic (Carroll, 1983). However, they position the organization as a good corporate citizen (Carroll, 1991). The second reason for the choice of this framework is that it has been empirically tested several times (Bir, Suher, \& Altinbasak, 2009).

CSR is defined as the entire range of business responsibilities an organization has towards society. It is represented in four types - namely, economic, legal, ethical, and discretionary responsibilities (Carroll, 1979). Carroll (1979) portrayed the four types of social responsibilities with the proportions of 4:3:2:1 respectively, implying the relative importance of each one.

First, the economic responsibility is defined as the responsibility of organizations to maximize profits from the production of goods and/or services to meet market needs (Carroll, 1979). Second, the legal responsibility is defined as the laws and regulations formulated and disseminated by national governments as the ground rules under which businesses must operate (Carroll, 1979). Third, the ethical responsibility entails the standards and norms that organizations should maintain to protect their stakeholders' moral rights; and which exceeds the frame of legal requirements. They reflect a concern for consumers, employees, shareholders, and the community at large, and what they view as fair and just (Carroll, 1979). Fourth, the discretionary 
responsibility is defined as the responsibilities that businesses take upon themselves voluntarily, through their desire to engage in non-mandated and unexpected social roles, and that are not even expected in an ethical sense (Carroll, 1979).

\section{Corporate Social Performance}

Corporate Social Performance (CSP) is a framework that helps to analyze, evaluate, and measure corporate social activities over time and across corporations, industries, or even nations (Sethi, 1975). One of the key milestones of CSP development is Carroll's 1979 CSP model. It is a three-dimensional model that defines social responsibility, lists the social issues involved, and delineates the philosophy of response to the social issues. In his model, Carroll (1979) started by defining social responsibility as the economic, legal, ethical, and discretionary responsibilities of organizations. Then he provided a listing of all areas of social responsibility issues that firms engage in, e.g. consumerism, environment, discrimination, product safety, occupational safety, and shareholders' issues. Carroll's third dimension is the philosophy or strategy adopted by the business as a response to the social issues. According to him, business philosophy/strategy lies somewhere in a continuum that ranges from doing nothing to doing much.

Wood (1991) took the framework of Carroll (1979) to a much broader and comprehensive model. Her model includes the principles of CSR, the processes of social responsiveness, and the outcomes of corporate behavior (Wood, 1991). First, the principles of CSR are the institutional legitimacy, the public responsibility, and the managerial discretion. Then, Wood (1991) outlined the processes of social responsiveness as the environmental assessment, stakeholder management, and social issues' management. Finally, the outcomes of corporate behavior include the social impacts, the social programs, and the social policies. In her model, Wood (1991) emphasized the outcomes of CSR which is an explicit contribution in the development of CSP.

In 2010, the International Standard Organization (ISO) launched ISO 26000 Social Responsibility (ISO - International Organization for Standardization, 2017). Unlike other ISO certifications, ISO 26000 is a voluntary international standard that provides all types of organizations in any country with global guidance and principles of social responsibility (ISO - International Organization for Standardization, 2017). It is intended to promote a common understanding in the field of social responsibility and encourage the implementation of best practices in social responsibility worldwide (ISO - International Organization for Standardization, 2017). In order to acquire 
international consensus, expert representation of different stakeholders' groups around the world was involved in its development (ISO - International Organization for Standardization, 2017). Its scope covers seven core subjects; terms and definitions, understanding social responsibility, principles of social responsibility, recognizing social responsibility and engaging stakeholders, guidance on social responsibility core subjects, guidance on integrating social responsibility throughout an organization, and examples of voluntary initiatives and tools for social responsibility (ISO International Organization for Standardization, 2017).

\section{Corporate Social Responsibility Practices}

CSR practices fall into two main categories (Misani, 2010). These are responsive/convergent CSR and strategic/divergent CSR (Misani, 2010). Firms following a responsive/convergent CSR are firms seeking to improve stakeholderrelationship and act as a good corporate citizen (Misani, 2010; Porter \& Kramer, 2006). While organizations which aspire for a competitive edge through a unique social performance, adopt a strategic/divergent CSR (Misani, 2010; Porter \& Kramer, 2006).

Most firms adopt a responsive/convergent CSR. They converge on a limited set of practices, imposed by the various stakeholders, to encourage them to build relationships and engage in business transactions (Barnett, 2007; Barreto \& BadenFuller, 2006; Misani, 2010). Positive CSR information influences potential investors' intentions to invest in the company, customers' decisions to purchase products, and potential employees to target specific organizations to work for (Alniacik, Alniacik, \& Genc, 2011). On the other hand, some firms try to achieve a competitive edge through adopting different CSR strategies (Misani, 2010). They build their unique image in trying to serve their stakeholders’ needs differently (Misani, 2010). In general, they combine their business opportunities with CSR activities, even if they are initially intended to address societal welfare (Misani, 2010).

\section{CSR and Creating Competitive Advantage}

Along with the development of CSR, scholars have been interested in studying the types of competitive advantage that organizations may acquire when demonstrating a good corporate social performance (Albinger \& Freeman, 2000; Sethi, 1975). Myriad researchers have associated CSR with diverse forms of competitive advantage. It has been associated with good financial performance (Bea, Pelham, \& Yuko, 2015; Heli \& Jaepil, 2013), cost reduction (Panwar, Nybakk, Hansen, \& Pinkse, 2016), word of mouth and customer retention (Saleh, Ebeid, \& Abdelhameed, 2015), 
employee retention (Bode, Singh, \& Rogan, 2015), job satisfaction and organizational commitment (Ching-Sing, Chun-Chen, Hsien-Bin, Kang-Ni, Chien-Hsiung, \& Ji-Shou, 2013), and organizational attractiveness (Evans \& Davis, 2011; Joo, Moon, \& Choi, 2016; Zaid \& Al-Manasra, 2013).

In an attempt to classify the types of competitive advantage obtained through CSR, Weber (2008) placed them into five main categories. These are positive company image and reputation, cost saving, CSR-related risk reduction or management, revenue increase from higher sales and market share, and human resources' motivation, retention, and attraction. Likewise, Nurn and Tan (2010) created another model that grouped the different forms of competitive advantage into external and internal categories. The external category includes corporate image and reputation, reducing business risk, boosting sales revenue and market share, customer goodwill, and increasing rivals' costs (Nurn \& Tan, 2010). Whereas learning, workplace attitude, employee motivation, employee morale, commitment, trust, employee loyalty/retention, organizational citizenship behaviors, and attracting better employees, exemplify the internal category (Nurn \& Tan, 2010).

\section{Employer Attractiveness}

Among the diverse forms of payback of CSR in the human resources management arena is employer attractiveness. It is defined as the job seekers' motivation and enthusiasm to hunt jobs and seek employment with an organization where they envision particular benefits in working for this specific firm (Berthon, Ewing, \& Hah, 2005). Berthon et al. (2005) proposed one of the most robust and empirically tested models to identify and operationalize the dimensions of employer attractiveness. According to them, employer attractiveness is composed of interest value, social value, economic value, development value, and application value.

First, the interest value examines the degree of a job seeker's attraction to an employer that provides a motivating work environment and that makes use of employees' creativity and innovation to produce high-quality and novel products and/or services (Berthon et al., 2005). Second, the social value represents the individual's attraction to organizations that provide a pleasant working environment, good working relationships, and a teamwork spirit (Berthon et al., 2005). Third, the economic value is defined as the level of attraction to an employer that offers a competitive total rewards package - including, compensation, benefits, job security, and promotional opportunities (Berthon et al., 2005). Fourth, the development value reflects the job seeker's attraction to an employer that demonstrates a recognition 
environment, coupled with career development and experience-building programs, and a springboard to future employment (Berthon et al., 2005). Fifth, the application value is defined as how attractive an employer is, that provides its employees with the opportunity to practically apply their theoretical knowledge in a knowledge-transfer environment, that is both customer-oriented and humanitarian (Berthon et al., 2005). Berthon et al. (2005) further explained that a humanitarian organization is the one that gives back to society. As such, Bergen (2008) suggested that the company's CSR practices are part of the humanitarian value.

\section{Employer Branding}

A closely related concept to the notion of employer attractiveness is employer branding (Berthon et al., 2005). Typically, branding activities are directed towards building up products and/or services’ brands (Backhaus \& Tikoo, 2004). Applying branding principles in the area of human resources management is termed employer branding (Backhaus \& Tikoo, 2004). It is defined as the efforts of the organization to communicate, to its current and potential employees, the unique and distinctive aspects of its employment offering, that makes it a great place to work for (Backhaus \& Tikoo, 2004; Berthon et al., 2005).

Cultivating an employer brand is a tool that is employed by organizations to recruit and retain the best caliber (Arachchige \& Robertson, 2013). Acquired caliber are expected to carry on the organization's brand success and secure an ongoing profitability of the firm (Arachchige \& Robertson, 2013). Thus, employer branding anchors on the belief that its outcomes will provide the company with a competitive edge (Arachchige \& Robertson, 2013).

\section{Individual's Income}

Individual's Income is defined as the flow of cash received from work in the form of wage or salary, or capital in the form of interest or profit, or land in the form of rental fees (Business Dictionary, 2017). In Egypt, salary/compensation is the main source of income for most of the working population. According to Berthon et al. (2005), compensation and benefits (non-cash compensation) and CSR activities, are two of the employer attractiveness dimensions represented by the economic and application values of organizations respectively. Individuals with an economic CSR orientation find a job more attractive when high compensation precedes organization's ethical values (Bir et al., 2009; Ray, 2006). Their preferences contrast with socially oriented individuals who perceive CSR as an indispensable ethical-fit condition of a company that yields an attractive employer (Kim \& Park, 2011). 


\section{The Relationship between CSR and Employer Attractiveness}

In the endeavor to understand the relationship between CSR and employer attractiveness, literature can be classified into three main findings. A considerable number of studies support the presence of a relationship between CSR and employer attractiveness (Backhaus, Stone, \& Heiner, 2002; Evans \& Davis, 2011; Greening \& Turban, 2000; Joo et al., 2016; Lis, 2012; Smith, Wokutch, Harrington, \& Dennis, 2004; Turban \& Greening, 1996; Zaid \& Al-Manasra, 2013). At the other extreme end, substantial research findings indicate that CSR is relatively unimportant as an attractive element of organizations, where other traditional job elements like salary and promotional opportunities are more essential (Bergen, 2008; Maheshwari \& Yadav, 2015; Pingle \& Sharma, 2013; Ramasamy et al., 2008; Sohn, Sohn, KlassWissing, \& Hirsch, 2015; Verma \& Ahmad, 2016). In between, a third collection of articles indicate that attraction to CSR differs amongst different countries, cultures, gender, CSR orientation, and educational and employment statuses. For some people, they represent an indispensable factor of job decision-making; whereas for others, CSR is not considered in the overall assessment of an employer (Albinger \& Freeman, 2000; Kang \& Alcantara, 2011; Ramasamy et al., 2008; Ray, 2006; Sorenson, Mattingly, \& Lee, 2010).

Empirically, many variables have either moderated or mediated this relationship. High levels of job-choice (Albinger \& Freeman, 2000), Person-Organization (P-O) fit (Behrend, Baker, \& Thompson, 2009), level of uncertainty in evaluating a potential employer (Bergen, 2008), employer branding (Gomes \& Neves, 2010), self-centered and other-centered motives (Joo et al., 2016), culture (Kang \& Alcantara, 2011), gender (Ramasamy et al., 2008; Ray, 2006), regions with more job choices, and more academic performance (Ramasamy et al., 2008), have been employed as moderating variables. Whereas, P-O fit (Kim \& Park, 2011; Zaid \& Al-Manasra, 2013), perceptions of organization's reputation (Behrend et al., 2009), firm familiarity (Luce, Barber, \& Hillman, 2001), and perceived overall justice (Joo et al., 2016), have mediated this relationship in previous studies.

\section{Research Gap}

The relationship between CSR and employer attractiveness has been investigated in many countries; in China, Taiwan, Hong Kong (Ramasamy et al., 2008), United States (Backhaus et al., 2002; Behrend et al., 2009; Evans \& Davis, 2011; Greening \& Turban, 2000; Kim \& Park, 2011; Luce et al., 2001; Ray, 2006; Smith et al., 2004; Turban \& Greening, 1996), Malaysia (Rahim, Sidik, \& Jalaludin, 2011), Spain 
(Gomes \& Neves, 2010), Pakistan (Shahzad et al., 2011), Norway (Bergen, 2008), Turkey (Bir et al., 2009), Germany (Sohn et al., 2015), India (Maheshwari \& Yadav, 2015; Pingle \& Sharma, 2013; Verma \& Ahmad, 2016), Korea (Joo et al., 2016), and Jordan (Zaid \& Al-Manasra, 2013). However, this relationship didn't attract the attention of scholars in Egypt. Additionally, a lot of variables have been employed as moderators and/or mediators in this relationship (as highlighted in the previous section); nonetheless the individual's income was not. In that view, it is essential to understand the relationship (if any) between CSR and employer attractiveness in Egypt. Furthermore, it is important to study the moderating effect of the individual's income on this relationship.

\section{HYPOTHESES DEVELOPMENT AND CONCEPTUAL FRAMEWORK}

Stakeholder's theory proposes that prospective employees are considered an important stakeholder whose concerns should be assimilated in CSR communication strategy (Edelman, 2008; Freeman \& McVea, 2001; Kim \& Park, 2011). A firm’s CSR communication provides signals about the internal working environment through reflecting its values and principles, as suggested by the signaling theory (Turban \& Greening, 1996). When making their job-choice decision, individuals receive CSR information and try to match their own needs and values with the organization's attributes, as explained by the P-O fit theory (Cable \& Judge, 1994). Hence, firms engaged in corporate social activities are more attractive employers as job applicants seek a better self-image through becoming members of a socially responsible firm, as proved by the social identity theory (Turban \& Greening, 1996). Therefore, it is proposed that:

$\mathrm{H}_{1}$ : There is a statistically significant positive relationship between an organization's CSR activities and its attractiveness as an employer in Egypt.

$\mathrm{H}_{1 \mathrm{a}}$ : There is a statistically significant positive relationship between economic behaviors of organizations and their attractiveness as employers in Egypt.

$\mathrm{H}_{1 \mathrm{~b}}$ : There is a statistically significant positive relationship between legal behaviors of organizations and their attractiveness as employers in Egypt.

$\mathrm{H}_{1 \mathrm{c}}$ : There is a statistically significant positive relationship between discretionary behaviors of organizations and their attractiveness as employers in Egypt.

As per Carroll's 1979 framework, CSR dimensions - namely, economic, legal, ethical, and discretionary dimensions have the relative importance of 4:3:2:1 proportions respectively. Hence, it is hypothesized that: 
$\mathrm{H}_{2}$ : The economic dimension has the highest effect on employer attractiveness in Egypt, followed by the legal dimension, and then the discretionary dimension.

According to the prepotency mechanism of Maslow's hierarchy of needs theory, individuals seek to satisfy their lower-order needs (physiological and safety needs) before their higher-order needs (social, self-esteem, and self-actualization needs) are stimulated (Robbins, 2005). Alderfer's ERG theory further supported Maslow's (Kessler, 2013). Alderfer proved that a person will not experience a desire for a certain need except after satisfying the most concrete and most dominant need (Kessler, 2013). Existence (lower-order/ physiological and security) needs are the most concrete and most dominant needs that individuals have a desire to satisfy before relatedness (social and esteem) or growth (self-actualization) needs (Kessler, 2013).

It is suggested that lower-order/ existence needs can be satisfied through economic plenty, that is represented by the individual's income. Whereas, belonging to a socially responsible organization can fulfill the individual's social needs, that is a higher-order/ relatedness need (Robbins, 2005). Therefore, a job seeker would pursue a relatively high income that satisfies his/her lower-order needs in the first place, before he/she seeks to belong to a socially responsible firm.

Moreover, the reservation wage theory proposes that a job seeker will not accept a job offer below his/her reservation wage level no matter how attractive the other job attributes are (Milkovich \& Newman, 2008). That is, if the pay level doesn't meet his/her minimum requirements, no other job attributes will make up for this insufficiency (Milkovich \& Newman, 2008). Hence, it is proposed that:

$\mathrm{H}_{3}$ : The individual's income moderates the relationship between CSR and employer attractiveness. 
Figure 1 provides a schematic diagram of the conceptual framework.

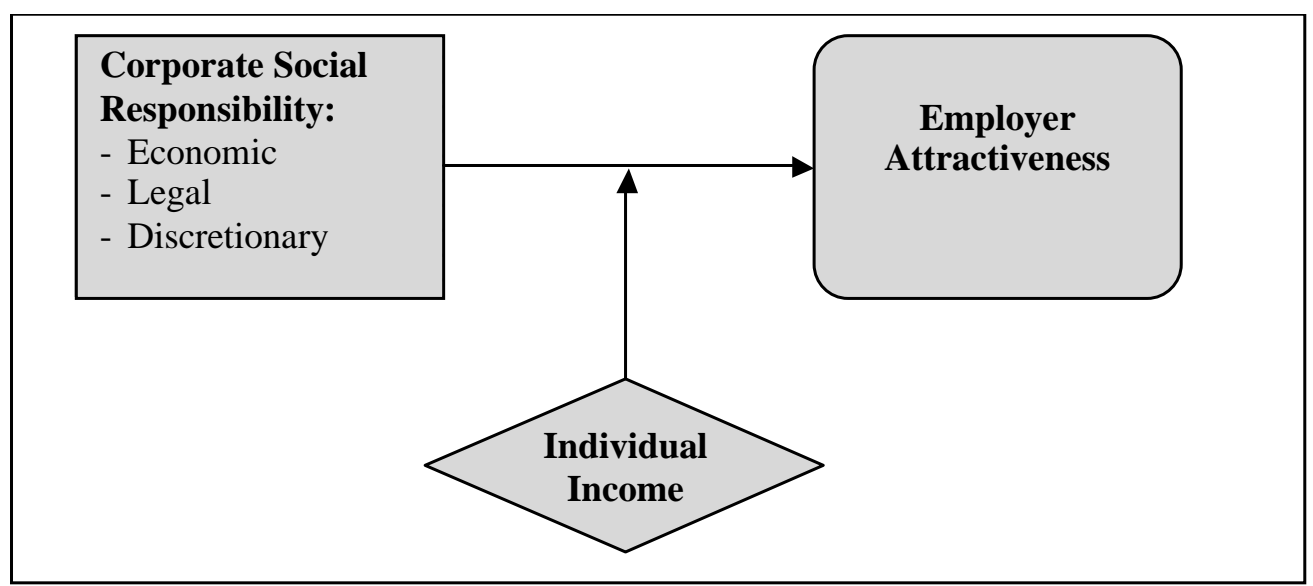

Figure 1 Conceptual Framework

\section{RESEARCH METHODOLOGY}

\section{Sampling Design}

Research population are Egyptian white-collar employees. Due to the unavailability of a sampling frame, the study opted for a non-probabilistic convenience sample of 1,050 Masters of Business Administration (MBA) students studying at a private university in Cairo. To guarantee a fairly representative sample, a highly-ranked yet financially affordable university was selected to ensure accessibility by the working population. MBA students are chosen for two reasons. First, they are highly educated individuals who are assumed to be most knowledgeable about organizations' CSR activities. Therefore, they can form an idea about the attractiveness of potential employers (Albinger \& Freeman, 2000; Greening \& Turban, 2000). Second, they are considered the highest caliber and most sought-after talent. Hence, they are assumed to possess the luxury to be selective even in tight labor markets (Albinger \& Freeman, 2000; Greening \& Turban, 2000).

\section{Instrument Design}

Quantitative primary data were collected through a questionnaire/survey method. The unit of analysis is individuals. The questionnaire/survey was designed adopting Bir et al. (2009) approach. Eight distinct CSR profiles were developed as measures of the independent variable CSR. With a deliberate manipulation in the description of high/low economic, high/low legal, and high/low discretionary behaviors, eight CSR profiles were created (as displayed in exhibit 1), using validated statements from the instrument of Aupperle, Carroll, and Hatfield (1985). They are referred to as 
organizations A through $\mathrm{H}$. For simplification reasons, the ethical dimension was excluded and the other three CSR dimensions were used to develop CSR profiles. The ethical dimension is an extension of the legal one; and since a lot of illegal business practices exist in Egypt, employees would typically seek employment with legally compliant companies more than ethically compatible ones.

Each CSR profile constituted a separate survey to measure the dependent variable employer attractiveness. Participants of each survey were requested to rate their attraction level to the presented CSR profile on a five-point Likert scale. The survey employed four validated employer attractiveness items from the instrument developed by Highhouse, Lievens, and Sinar (2003). These are: "For me, this company would be a great place to work for", "I would choose this company as one of my first choices for an employer", "I would find a job with this company attractive", and "I would exert a great deal of effort to work for this company".

The moderating variable, the individual's income, was collected in the demographics section of the survey.

Exhibit 1 Organizational CSR Profiles

\begin{tabular}{|c|c|c|c|}
\hline $\begin{array}{l}\text { Organization A } \\
\text { (Low-Low-Low) }\end{array}$ & $\begin{array}{l}\text { Organization B } \\
\text { (Low-Low-High) }\end{array}$ & $\begin{array}{l}\text { Organization C } \\
\text { (Low-High-Low) }\end{array}$ & $\begin{array}{l}\text { Organization D } \\
\text { (High-Low-Low) }\end{array}$ \\
\hline $\begin{array}{l}\text { Low Economic } \\
\text { Low Legal } \\
\text { Low Discretionary }\end{array}$ & $\begin{array}{l}\text { Low Economic } \\
\text { Low Legal } \\
\text { High Discretionary }\end{array}$ & $\begin{array}{l}\text { Low Economic } \\
\text { High Legal } \\
\text { Low Discretionary }\end{array}$ & $\begin{array}{l}\text { High Economic } \\
\text { Low Legal } \\
\text { Low Discretionary }\end{array}$ \\
\hline $\begin{array}{l}\text { Organization E } \\
\text { (Low-High-High) }\end{array}$ & $\begin{array}{l}\text { Organization F } \\
\text { (High-Low-High) }\end{array}$ & $\begin{array}{l}\text { Organization G } \\
\text { (High-High-Low) }\end{array}$ & $\begin{array}{l}\text { Organization H } \\
\text { (High-High-High) }\end{array}$ \\
\hline $\begin{array}{l}\text { Low Economic } \\
\text { High Legal } \\
\text { High Discretionary }\end{array}$ & $\begin{array}{l}\text { High Economic } \\
\text { Low Legal } \\
\text { High Discretionary }\end{array}$ & $\begin{array}{l}\text { High Economic } \\
\text { High Legal } \\
\text { Low Discretionary }\end{array}$ & $\begin{array}{l}\text { High Economic } \\
\text { High Legal } \\
\text { High Discretionary }\end{array}$ \\
\hline
\end{tabular}

Source: the author modified Bir, et al., 2009, p.2310

\section{Data Collection Procedures}

MBA students were divided systematically into eight equal groups. Each of the eight groups received one of the eight questionnaires by email. This quasiexperimental design was adopted not to test causality, but to avoid social desirability of respondents. Put differently, if each respondent was exposed to the eight profiles, he/she would rate the highest CSR profile as the most attractive. 


\section{ANALYSIS AND RESULTS}

\section{Sample Characteristics}

Data collection yielded 383 observations with an overall response rate of $36.5 \%$. 370 observations were valid and complete. Most of the participants were males (76.2\%), and the majority (61.6\%) were in the 31 to 40 years old category. Around half of them (51.4\%) were married with children, and the rest were almost equally distributed between either married or single categories. Almost all of them (93.2\%) were full-time employees; occupying one of three seniority level positions, middle management (40\%), top management (26.2\%), or a senior-level (18.6\%). A substantial percentage (40\%) were actively looking for a job. The individual's monthly income of the sample was almost equally distributed among three categories, “less than or equal to 10k EGP” (33.2\%), "between 10,001 and 20k EGP” (30.5\%), and "more than 20k EGP” (36.2\%).

\section{Instrument Reliability}

Internal consistency analysis for employer attractiveness yielded a highly reliable Cronbach’s alpha coefficient of 0.892 .

\section{Results of Hypotheses Testing}

One-way Analysis of Variance (ANOVA) and Scheffe Post-Hoc tests were used to test $\mathrm{H}_{1}$. Results indicate that employer attractiveness mean scores of the CSR profiles (A through $\mathrm{H}$ ) are significantly different $(\mathrm{p}=0.000)$. Scheffe Post-Hoc test grouped organizations with similar employer attractiveness mean scores into 5 groups (as shown in table 1). Organization $\mathrm{A}$ has the lowest employer attractiveness mean score $(M=1.5833)$, followed by organizations $B, C$, and $D$ with almost similar mean scores (between 2.0 and 2.5), then organizations $\mathrm{E}$ and $\mathrm{F}$ ( $\mathrm{M}$ between 2.5 and 3), then organization $G(M=3.425)$, and finally organization $H$ with the highest employer attractiveness mean score $(M=4.1768)$. It is noticeable that employer attractiveness mean scores increase as CSR activities increase. Hence, $\mathrm{H}_{1}$ which states that "there is a statistically significant positive relationship between an organization's CSR activities and its attractiveness as an employer in Egypt” is supported. Results also reveal that there is a strong relationship between CSR and employer attractiveness (eta correlation coefficient $=0.731)$. 
Table 1 Scheffe Post-Hoc Test for $\mathrm{H}_{1}$

\begin{tabular}{|l|r|r|r|r|r|r|}
\hline \multirow{2}{*}{ Organization } & $\mathrm{N}$ & 1 & 2 & 3 & 4 & 5 \\
\cline { 2 - 6 } & 60 & 1.5833 & & & & \\
$\mathrm{~B}$ & 59 & & 2.0678 & & & \\
$\mathrm{C}$ & 45 & & 2.0722 & & & \\
$\mathrm{D}$ & 47 & & 2.4628 & & & \\
$\mathrm{E}$ & 47 & & & 2.5426 & & \\
$\mathrm{~F}$ & 31 & & & 2.8306 & \\
$\mathrm{G}$ & 40 & & & & 3.4250 & \\
$\mathrm{H}$ & 41 & & & & \\
Sig. & & .196 & .230 & .584 & 1.000 & 1.000 \\
\hline Means for groups in homogeneous subsets are displayed. \\
a. Uses Harmonic Mean Sample Size = 44.435. \\
b. The group sizes are unequal. The harmonic mean of the group sizes \\
is used. Type I error levels are not guaranteed. \\
\hline
\end{tabular}

As for the three minor hypotheses $\mathrm{H}_{1 \mathrm{a}}, \mathrm{H}_{1 \mathrm{~b}}$, and $\mathrm{H}_{1 \mathrm{c}}$, one-way ANOVA test was used. Organizations were arranged in pairs of high and low levels of each CSR dimension (as shown in table 2). One-way ANOVA compared employer attractiveness mean scores of each low and high-performing pair.

The first minor hypothesis $\mathrm{H}_{1 \mathrm{a}}$ states that "there is a statistically significant positive relationship between economic behaviors of organizations and their attractiveness as employers in Egypt”. Respondents' ratings to low economic organizations were significantly different $(p=0.000)$ than their ratings to high economic organizations. Supporting $\mathrm{H}_{1 \mathrm{a}}$, low economic organizations $(\mathrm{M}=2.0367$, $\mathrm{SD}=0.75602)$ were rated lower than high economic organizations $(\mathrm{M}=3.2186, \mathrm{SD}=$ 1.03298).

The second minor hypothesis $\mathrm{H}_{1 \mathrm{~b}}$ states that "there is a statistically significant positive relationship between legal behaviors of organizations and their attractiveness as employers in Egypt”. Respondents rated low legal organizations versus high legal organizations significantly different $(\mathrm{p}=0.000)$. Supporting $\mathrm{H}_{1 \mathrm{~b}}$, low legal organizations $(\mathrm{M}=2.1345, \mathrm{SD}=.89624)$ were rated less attractive than high legal organizations $(\mathrm{M}=3.0116, \mathrm{SD}=1.04263)$.

The third minor hypothesis $\mathrm{H}_{1 \mathrm{c}}$ states that "there is a statistically significant positive relationship between discretionary behaviors of organizations and their attractiveness as employers in Egypt". Respondents rated low discretionary organizations versus high discretionary organizations significantly different $(p=0.000)$. Supporting $\mathrm{H}_{1 \mathrm{c}}$, low discretionary organizations $(\mathrm{M}=2.2969, \mathrm{SD}=.98038)$ are less 
appealing than high discretionary organizations $(\mathrm{M}=2.8118, \mathrm{SD}=1.08194)$.

Table 2 Mean Scores for First Minor Hypotheses

\begin{tabular}{|l|l|l|l|r|}
\hline & & Mean & N & $\begin{array}{c}\text { Std. } \\
\text { Deviation }\end{array}$ \\
\hline Pair 1 & Low economic organizations (A, B, C, E) & 2.0367 & 211 & .75602 \\
& High economic organizations (D, F, G, H) & 3.2186 & 159 & 1.03298 \\
\hline Pair 2 & Low legal organizations (A, B, D, F) & 2.1345 & 197 & .89624 \\
& High legal organizations (C, E, G, H) & 3.0116 & 173 & 1.04263 \\
\hline Pair 3 & Low discretionary organizations (A, C, D, G) & 2.2969 & 192 & .98038 \\
& High discretionary organizations (B, E, F, H) & 2.8118 & 178 & 1.08194 \\
\hline
\end{tabular}

Although the three hypotheses were supported, results show that the strength of the relationship between each CSR dimension and employer attractiveness is different. There is a moderate relationship between the economic dimension and employer attractiveness (eta correlation coefficient $=0.552$ ), and between the legal dimension and employer attractiveness (eta correlation coefficient of 0.413). Whereas, the relationship between the discretionary dimension and employer attractiveness is weak (eta correlation coefficient $=0.243$ ), as displayed in table 3 .

Table 3 Correlation Coefficient and Coefficient of Determination

\begin{tabular}{|l|r|r|}
\hline & \multicolumn{1}{|c|}{ Eta } & Eta Squared \\
\hline Employer Attractiveness * Economic & .552 & .305 \\
\hline Employer Attractiveness * Legal & .413 & .171 \\
\hline Employer Attractiveness * Discretionary & .243 & .059 \\
\hline
\end{tabular}

Results also show that the economic dimension has the highest effect on employer attractiveness with a coefficient of determination (Eta squared) of 0.305. The effect of the legal dimension comes next with a coefficient of determination of 0.171. Then the discretionary dimension has the lowermost effect with a coefficient of determination of 0.059 . Thus, hypothesis $\mathrm{H}_{2}$ which states that "the economic dimension has the highest effect on employer attractiveness in Egypt, followed by the legal dimension, and then the discretionary dimension” is supported.

As for $\mathrm{H}_{3}$, two-way ANOVA tested the interaction effect of the independent and the moderating variables on the dependent variable, i.e. the interaction effect of CSR and the individual's income on the employer attractiveness. Results were insignificant $(\mathrm{p}=0.484)$ as shown in table 4 . Therefore, $\mathrm{H}_{3}$ which states that "the individual's 
income moderates the relationship between CSR and employer attractiveness” is not supported.

Table 4 Two-way ANOVA for Third Hypothesis

\begin{tabular}{|l|r|r|r|r|r|r|}
\hline & $\begin{array}{c}\text { Type III } \\
\text { Sum of } \\
\text { Squares }\end{array}$ & \multicolumn{1}{c|}{ df } & $\begin{array}{c}\text { Mean } \\
\text { Square }\end{array}$ & \multicolumn{1}{c|}{$\mathrm{F}$} & Sig. & $\begin{array}{c}\text { Partial } \\
\text { Eta } \\
\text { Squared }\end{array}$ \\
\hline Corrected Model & $229.359^{\mathrm{a}}$ & 23 & 9.972 & 18.560 & .000 & .552 \\
Intercept & 2405.715 & 1 & 2405.715 & 4477.424 & .000 & .928 \\
Organization & 221.942 & 7 & 31.706 & 59.010 & .000 & .544 \\
Income & .065 & 2 & .033 & .061 & .941 & .000 \\
Organization * Income & 7.297 & 14 & .521 & .970 & .484 & .038 \\
Error & 185.905 & 346 & .537 & & & \\
Total & 2811.000 & 370 & & & & \\
Corrected Total & 415.264 & 369 & & & & \\
\hline
\end{tabular}

a. R Squared $=.552$ (Adjusted R Squared $=.523$ )

\section{DISCUSSION}

Becoming increasingly aware of the benefits of CSR, organizations are nowadays incorporating CSR activities in their business strategies. It helps them enjoy many forms of competitive advantage when acting in a socially responsible manner. Human resources attraction is one of these forms. On the other hand, one of the major challenges that organizations are facing nowadays is the global talent shortage. The challenge is manifold for businesses in Egypt. First, despite the high quantity, the quality of supply mismatches that of demand. Second, globalization eased expatriation of skilled labor and companies are fiercely competing to attract the remaining talent. Hence, talent attraction comes on top of the human resources management agenda in Egypt.

Scholars didn't pay attention to the area of CSR and employer attractiveness in Egypt. Likewise, they didn't the examine assumption that the individual's income moderates this relationship. This study aims at tackling these gaps.

Results show that there is a positive relationship between an organization's CSR activities and its attractiveness as an employer in Egypt. They also reveal that each individual dimension of CSR - namely, economic, legal, and discretionary, has a positive relationship with employer attractiveness. These results are in line with most of the studies examining the relationship between CSR and employer attractiveness (Backhaus et al., 2002; Evans \& Davis, 2011; Greening \& Turban, 2000; Joo et al., 2016; Lis, 2012; Luce et al., 2001; Rahim et al., 2011; Smith et al., 2004; Turban \& Greening, 1996; Zaid \& Al-Manasra, 2013). It is also proved that CSR influences job- 
choice decisions in China and Taiwan (Ramasamy et al., 2008). Similarly, CSR is an important decision factor for joining an organization in Malaysia (Rahim et al., 2011). Likewise, in Pakistan, organizations can attract high quality employees through focusing on employer branding dimensions, including CSR (Shahzad et al., 2011).

Contrarily, Bergen (2008) suggests that Norwegian job candidates do not consider CSR as an important element in their overall assessment of an organization. Firms emphasizing specific qualities like employee recognition or job security, rather than highlighting their ethical behavior, motivate Norwegian job candidates to accept the offered position (Bergen, 2008). Similarly, CSR is relatively unimportant to job seekers in Hong Kong, in comparison with salary and other traditional job attributes like work location (Ramasamy et al., 2008). For Indian job seekers, CSR comes the last on the list of employer attractiveness factors in favor of learning and development, employee recognition (Pingle \& Sharma, 2013), social and friendly environment, compensation package, cooperation value, and exciting working environment (Verma \& Ahmad, 2016). Moreover, they consider CSR not more than a hygiene factor versus other employer attractiveness factors, i.e. role/job offered, career opportunities, and compensation (Maheshwari \& Yadav, 2015).

Results also prove that the economic dimension has the highest effect on employer attractiveness, followed by the legal dimension, and then the discretionary one. The ultimate importance of the economic dimension is attributed to the fact that Egypt is an emerging economy. Additionally, the unstable political situation after the 2011 revolution and the persistent political turmoil have a dramatic impact on the economic situation. It has led many companies to downsize or withdraw from the Egyptian market. As such, employees would initially seek employment with an economically stable and solid company. Moreover, the illegal employment practices and the corrupted business transactions that surround the business environment in Egypt might have an influence as well. Hence, legal compliance would be more essential than discretionary-related activities. Ultimately, the underdeveloped context in Egypt led respondents to get more attracted to the most fundamental business responsibilities over the relative secondary ones (Carroll, 1979).

These results align with Carroll's 1979 framework; whereby the economic, legal, ethical, and discretionary dimensions of CSR have a relative importance of 4:3:2:1 respectively. They are also comparable with the results of Bir et al. (2009), whereby organizations with a high economic power are considered the most attractive, followed by those acting according to the ethical values, and finally those paying attention to their discretionary responsibilities. Consistently, business and product related CSR activities are more attractive to human resources than discretionary 
activities (Kang \& Alcantara, 2011). Likewise, 'self-centered' CSR activities, that aim at increasing economic gains and firm-serving benefits, are more attractive to job applicants than 'other-centered' motives, that aim at fulfilling obligations towards society (Joo et al., 2016).

Finally, findings indicate that the relationship between CSR and employer attractiveness is not moderated by the individual's income. Some arguments can account for this result. First, a sample drawn from one university with low variance in the individual's income might have affected the results. Second, the individual's income was measured as a categorical variable rather than an exact measurement as a scale variable. Third, mistrusting the anonymity of the survey might have impacted the individual's income disclosure.

\section{PRACTICAL IMPLICATIONS}

The results of this research adds new evidence to the growing body of literature suggesting that CSR yields a competitive advantage in the labor marketplace. It provides valuable insights and recommendations to organizations operating in Egypt on how to differentiate themselves and win the war over talent. Two main findings and relative practical interventions can be considered strategically in human resources management.

First, results suggest that employer attractiveness is one of the competitive advantages gained through CSR. Put differently, a socially responsible organization is an attractive employer for prospective employees. This finding is a gateway to talent acquisition. Organizations can use CSR as a reputation and image management strategy to overcome the widespread talent shortage setback. Deploying an employer branding strategy is a practical intervention that portrays the organization as an employer-of-choice. Initially, firms can create an employer value proposition and represent it in its employment brand. Then, the internal and external marketing should shed the light on the unique and distinctive employment attributes of the employment brand.

Second, findings reveal that the economic and legal responsibilities have a higher impact on employer attractiveness than the discretionary ones. Achieving a resilient and solid financial position in addition to abiding by the applicable laws and regulations have a substantial significance for job seekers over the charitable activities. Thus, to win the war over talent, businesses need a meticulous CSR profile management. They should direct more attention to establishing their most fundamental social responsibilities, i.e. the economic and legal responsibilities, and 
subsequently build their discretionary ones. In addition, they need to emphasize their economic and discretionary activities in their employment brand over their discretionary behaviors.

\section{LIMITATIONS AND RECOMMENDATIONS FOR FUTURE RESEARCH}

Some limitations can be recognized in the study. First, despite the sizable sample and the sample selection criteria, it may not be representative enough. Admission and selection standards of MBA students in one university may have influenced the sample characteristics, and consequently impacted the results. Moreover, the study doesn't take the demographic differences into consideration, which may have an influence on the job-choice decision, e.g. job level, gender, age, marital status, ... etc. Furthermore, it doesn't differentiate between individuals in the different recruitment and selection stages, i.e. job seekers, job applicants, and potential employees. Job seekers and job applicants may view CSR different from those involved in later jobchoice decisions.

The results of the study and its limitations provide some insights that dictate further research on the topic. Initially, future research can consider the above limitations, i.e. a more representative sample, the demographic differences, and individuals in the different recruitment and selection stages. Perhaps these considerations yield a moderating role of the individual's income on the relationship. In addition, a more precise estimate of the individual's reservation wage level can be examined in details in future research. The conceptual framework assumes that the presence of a reservation wage level that satisfies the individual's lower-order needs should be met first in order for the job seeker to consider other organizational attributes. Both the individual's income and his/her expenditures are equally important factors in the estimation of the reservation wage level. As such, factors influencing the individual's expenditures, e.g. the number of dependents and the living standard, may be useful to consider. Finally, future research can consider the offered salary, rather than the current salary, in measuring the individual's income. An individual's income depends mainly on his/her salary, especially for most of the working population in Egypt. Therefore, providing salary-related information along with CSR information, would ease an educated employment decision-making.

\section{REFERENCES}

Ahmed, M., Guillaume, D., \& Furceri, D. (2012). Youth Unemployment in the MENA Region: Determinants and Challenges. Retrieved from IMF website: http://www.imf.org/external/np/vc/2012/061312.htm 
Albinger, H. S., \& Freeman, S. J. (2000). Corporate Social Performance and Attractiveness as an Employer to Different Job Seeking Populations. Journal of Business Ethics, 28(3), 243-253. https://doi.org/10.1023/A:1006289817941

Alniacik, U., Alniacik, E., \& Genc, N. (2011). How Corporate Social Responsibility Information Influences Stakeholders' Intentions. Corporate Social Responsibility and Environmental Management, 234-245. http://dx.doi.org/10.1002/csr.245

Arachchige, B. J., \& Robertson, A. (2013). Employer Attractiveness: Comparative Perceptions of Undergraduate and Postgraduate Students. Sri Lankan Journal of Human Resource Management, 4(1), 33-48. http://dx.doi.org/10.4038/sljhrm.v4i1.5616

Aupperle, K. E., Carroll, A. B., \& Hatfield, J. D. (1985). An Empirical Examination of the Relationship between Corporate Social Responsibility and Profitability. Academy of Management Journal, 28(2), 446-463. http://dx.doi.org/10.2307/256210

Backhaus, K. B., Stone, B. A., \& Heiner, K. (2002). Exploring the Relationship between Corporate Social Performance and Employer Attractiveness. Business and Society, 41(3), 292-318. http://dx.doi.org/10.1177/0007650302041003003

Backhaus, K., \& Tikoo, S. (2004). Conceptualizing and Researching Employer Branding. Career Development International, 9(5), 501-517. http://dx.doi.org/10.1108/13620430410550754

Barnett, M. L. (2007). Stakeholder Influence Capacity and the Variability of Financial Returns to Corporate Social Responsibility. Academy of Management Review, 32(3), 794-816. http://dx.doi.org/10.5465/AMR.2007.25275520

Barreto, I., \& Baden-Fuller, C. (2006). To Conform or to Perform? Mimetic Behavior, Legitimacy-Based Groups and Performance Consequences. Journal of Management Studies, 43(7), 1559-1581. http://dx.doi.org/10.1111/j.14676486.2006.00620.x

Bea, C., Pelham, A., \& Yuko, K. (2015). Environmental Costs, Social Responsibility and Corporate Financial Performance - A Closer Examination of Japanese Companies. American Journal of Business Research, 8(1), 39-56.

Behrend, T. S., Baker, B. A., \& Thompson, L. F. (2009). Effects of ProEnvironmental Recruiting Messages: The Role of Organizational Reputation. Journal of Business and Psychology, 24(3), 341-350. http://dx.doi.org/10.1007/s10869-009-9112-6 
Bergen, H. C. (2008). Employer Attractiveness: What Effect Does CSR Have, and How Can Organizations Become Attractive to Norwegian Business Students? (Master's Thesis). The Norwegian School of Economics and Business Administration. Retrieved from: http://www.bi.edu/PageFiles/139283/.

Berthon, P., Ewing, M., \& Hah, L. L. (2005). Captivating Company: Dimensions of Attractiveness in Employer Branding. International Journal of Advertising, 24(2), 151-172. http://dx.doi.org/10.1080/02650487.2005.11072912

Bir, C. S., Suher, I. K., \& Altinbasak, I. (2009). Corporate Social Responsibility Orientation and Employer Attractiveness. Journal of Yasar University, 4(15), 2303-2326.

Birdsall, N., \& O’Connell, L. (1999). Putting Education to Work in Egypt. Paper Presented at Growth Beyond Stabilization: Prospects for Egypt, Retrieved from: http://www.cgdev.org/doc/expert pages/EgyptMar15.pdf

Bode, C., Singh, J., \& Rogan, M. (2015). Corporate Social Initiatives and Employee Retention. Organization Science, 26(6), 1702-1720. http://dx.doi.org/10.1287/orsc.2015.1006

Business Dictionary (2017). Income. Retrieved on May 26, 2017, from http://www.businessdictionary.com/definition/income.html

Cable, D. M., \& Judge, T. A. (1994). Pay Preferences and Job Search Decisions: A Person-Organization Fit Perspective. Personnel Psychology, 47(2), 317-348. http://dx.doi.org/10.1111/j.1744-6570.1994.tb01727.x

Carroll, A. B. (1979). A three-dimensional Conceptual Model of Corporate Social Performance. Academy of Management Review, 4(4), 497-505. http://dx.doi.org/10.5465/AMR.1979.4498296

Carroll, A. B. (1983). Corporate Social Responsibility: Will Industry Respond to Cutbacks In Social Program Funding? Vital Speeches of the Day, 49(19), 604608. http://dx.doi.org/10.1177/000765039903800303

Carroll, A. B. (1991). The Pyramid of Corporate Social Responsibility: Toward the Moral Management of Organizational Stakeholders. Business Horizons, 34(4), 39-48. http://dx.doi.org/10.1016/0007-6813(91)90005-G

Carroll, A. B. (1999). Corporate Social Responsibility: Evolution of a Definitional $\begin{array}{llll}\text { Construct. Business } \quad \text { and } & \text { Society, }\end{array}$ http://dx.doi.org/10.1177/000765039903800303

Ching-Sing, Y., Chun-Chen, H., Hsien-Bin, W., Kang-Ni, L., Chien-Hsiung, L., \& JiShou, T. (2013). The Relationship between Corporate Social Responsibility, Job Satisfaction and Organizational Commitment. International Journal of Organizational Innovation, 5(4), 65-77. 
Edelman, C. D. (2008). Corporate Responsibility \& Sustainability Communications: Who's Listening? Who's Leading? What Matters Most? New York: Edelman.

Evans, W. R., \& Davis, W. D. (2011). An Examination of Perceived Corporate Citizenship, Job Applicant Attraction, and CSR Work Role Definition. Business and Society, 50(3), 456-480. http://dx.doi.org/10.1177/0007650308323517

Freeman, R. E., \& McVea, J. (2001). A Stakeholder Approach to Strategic Management (Darden Business School Working Paper No. 01-02). Retrieved from Social Science Research Network website: http://ssrn.com/abstract=263511.

Galal, A. (2002). The Paradox of Education and Unemployment in Egypt (The Egyptian Center for Economic Studies Working Paper No.67). Retrieved from Egyptian Center for Economic Studies website: http://www.eces.org.eg/MediaFiles/Uploaded_Files/\%7BB6065D33-E098-455B8287-17E03C608A79\%7D_ECESWP67.pdf

Gomes, D. R., \& Neves, J. (2010). Employer Branding Constrains Applicants' Job Seeking Behavior? Revista de Psicología del Trabajo y de las Organizaciones, 26(3), 223-234. http://dx.doi.org/10.5093/tr2010v26n3a6.

Greening, D. W., \& Turban, D. B. (2000). Corporate Social Performance as a Competitive Advantage in Attracting a Quality Workforce. Business and Society, 39(3), 254-280. http://dx.doi.org/10.1177/000765030003900302

Hassan, M., \& Sassanpour, C. (2008). Labor Market Pressures in Egypt: Why is the Unemployment Rate Stubbornly High? Journal of Development and Economic Policies, 10(2), 79-115.

Heli, W., \& Jaepil, C. (2013). A New Look at the Corporate Social-Financial Performance Relationship: The Moderating Roles of Temporal and Interdomain Consistency in Corporate Social Performance. Journal of Management, 39(2), 416-441.

Highhouse, S., Lievens, F., \& Sinar, E. (2003). Measuring Attraction to Organizations. Educational and Psychological Measurement, 63(6), 986-1001. http://dx.doi.org/10.1177/0013164403258403

ISO - International Organization for Standardization (2017). ISO 26000:2010 Guidance on Social Responsibility. Retrieved on May 26, 2017, from https://www.iso.org/standard/42546.html

Joo, Y. R., Moon, H. K., \& Choi, B. K. (2016). A Moderated Mediation Model of CSR and Organizational Attractiveness Among Job Applicants. Management Decision, 54(6), 1269-1293. http://dx.doi.org/10.1108/MD-10-2015-0475 
Kang, S. K., \& Alcantara, L. L. (2011). The Impact of Corporate Social Responsibility Activities On Organizational Attractiveness Across Different Cultures. International Employment Relations Review, 17(2), 37-54.

Kessler, E. H. (2013). Encyclopedia of Management Theory. Thousand Oaks, California: Sage Publications. http://dx.doi.org/10.4135/9781452276090

Kim, S., \& Park, H. (2011). Corporate Social Responsibility as an Organizational Attractiveness for Prospective Public Relations Practitioners. Journal of Business Ethics, 103(4), 639-653. http://dx.doi.org/10.1007/s10551-011-0886-x

Lis, B. (2012). The Relevance of Corporate Social Responsibility for a Sustainable Human Resource Management: An Analysis of Organizational Attractiveness as a Determinant in Employees' Selection of a (Potential) Employer. Management Revue, 23(3), 279-295.

Luce, R. A., Barber, A. E., \& Hillman, A. J. (2001). Good Deeds and Misdeeds: A Mediated Model of the Effect of Corporate Social Performance on Organizational Attractiveness. Business and Society, 40(4), 397-415. http://dx.doi.org/10.1177/000765030104000403

Maheshwari, S., \& Yadav, R. (2015). Is CSR a Hygiene Factor for Prospective Employees? An Indian Exploration. Indian Journal of Industrial Relations, 50(4), 601-612.

Milkovich, G. T., \& Newnam, J. M. (2008). Compensation. New York: McGraw Hill. Misani, N. (2010). The Convergence of Corporate Social Responsibility Practices.
Management
Research
Review,
33(7),
734-748.

http://dx.doi.org/10.1108/01409171011055816

Nurn, C. W., \& Tan, G. (2010). Obtaining Intangible and Tangible Benefits from Corporate Social Responsibility. International Review of Business Research Papers, 6(4), 360-371.

Panwar, R., Nybakk, E., Hansen, E., \& Pinkse, J. (2016). The Effect of Small Firms' Competitive Strategies on Their Community and Environmental Engagement. $\begin{array}{lll}\text { Journal of Cleaner } \quad \text { Production, 129, } & \text { 578-585. }\end{array}$ http://dx.doi.org/10.1016/j.jclepro.2016.03.141

Pingle, S. S., \& Sharma, A. (2013). External Employer Attractiveness: A Study of Management Students in India. Journal of Contemporary Management Research, 7(1), 78-95.

Porter, M. E., \& Kramer, M. R. (2006). Strategy and Society: The Link between Competitive Advantage and Corporate Social Responsibility. Harvard Business Review, 85(6), 136-137. https://doi.org/10.1108/sd.2007.05623ead.006 
Rahim, R. A., Sidik, M. H. J., \& Jalaludin, F. W (2011). The Importance of Corporate Social Performance to the Prospective Employees in Malaysia. Journal of Social Sciences and Humanities, 1258-1279

Ramasamy, B., Yeung, M., \& Yuan, Y. (2008). The Role of Corporate Social Responsibility (CSR) in Job Choice Decisions in the Greater China Region. Paper presented at EU-CHINA BMT Conference Papers and Proceedings, the 2nd World Business Ethics Forum (pp. 1-24). Retrieved from http://www.lujiazuiforum.org/bmt/images/20081217/14283.pdf.

Ray, J. R. (2006). Investigating Relationships between Corporate Social Responsibility Orientation and Employer Attractiveness (Doctoral dissertation). George Washington University.

Robbins, S. P. (2005). Essentials of Organizational Behavior. New Jersey: Pearson Education.

Saleh, M. T., Ebeid, A. Y., \& Abdelhameed, T. A. (2015). Customers' Perception of Corporate Social Responsibility (CSR): Its Impact on Word-of-Mouth and Retention. Innovative Marketing, 11(2), 49-55.

Sethi, S. P. (1975). Dimensions of Corporate Social Performance: An Analytical Framework. California Management Review, 17(3), 58-64. http://dx.doi.org/10.2307/41162149

Shahzad, K., Gul, A., Khan, K., \& Zafar, R. (2011). Relationship between Perceived Employer Branding and Intention to Apply: Evidence from Pakistan. European Journal of Social Science, 18(3), 462-467.

Smith, W. J., Wokutch, R. E., Harrington, K. V., \& Dennis, B. S. (2004). Organizational Attractiveness and Corporate Social Orientation: Do Our Values Influence Our Preference for Affirmative Action and Managing Diversity? $\begin{array}{llll}\text { Business } \quad \text { and } & \text { Society, }\end{array}$ http://dx.doi.org/10.1177/0007650304263047

Sohn, M., Sohn, W., Klaas-Wissing, T., \& Hirsch, B. (2015). The influence of Corporate Social Performance on Employer Attractiveness in the Transport and Logistics Industry. International Journal of Physical Distribution \& Logistics Management, 45(5), 486-505. http://dx.doi.org/10.1108/IJPDLM-07-2014-0150 Sorenson, S., Mattingly, J. E., \& Lee, F. K. (2010). Decoding the Signal Effects of Job Candidate Attraction to Corporate Social Practices. Business and Society Review, 115(2), 173-204. http://dx.doi.org/10.1111/j.1467-8594.2010.00361.x

Sousa Filho, J. M., Wanderley, L. S. O., Gómez, C. P., \& Farache, F. (2010). Strategic Corporate Social Responsibility Management for Competitive Advantage. 
Brazilian Administration Review, 7(3), 294-309. http://dx.doi.org/10.1590/S1807-76922010000300006

Turban, D. B., \& Greening, D. W. (1996). Corporate Social Performance and Organizational Attractiveness to Prospective Employees. Academy of Management Journal, 40(3), 658-672. http://dx.doi.org/10.2307/257057

U.S. Department of the Army (1998). Country Studies/Area Handbook Series. New York: Federal Research Division of the Library of Congress. Retrieved from http://countrystudies.us/egypt.

Verma, D., \& Ahmad, A. (2016). Employer Branding: The Solution to Create Talented Workforce. IUP Journal of Brand Management, 13(1), 42-56.

Weber, M. (2008). The Business Case for Corporate Social Responsibility: A Company-level Measurement Approach for CSR. European Management Journal, 26(4), 247-261. http://dx.doi.org/10.1016/j.emj.2008.01.006

Wood, D. J. (1991). Corporate Social Performance Revisited. Academy of Management $\quad$ Review, 16(4), 691-718. http://dx.doi.org/10.5465/AMR.1991.4279616

Zaid, M. K. S. A., \& Al-Manasra, E. A. (2013). The Impact of Corporate Social Responsibility Dimensions on Organizational Attractiveness in Jordanian Commercial Banks. European Journal of Business and Management, 5(12), 175183. 
